\title{
KRITIK TERHADAP REKONSTRUKSI METODE PEMAHAMAN HADIS MUHAMMAD AL-GHAZALI
}

\author{
Sri Purwaningsih \\ Universitas Islam Negeri Walisongo Semarang \\ e-mail: spurwaningsih17@gmail.com
}

\begin{abstract}
Muhammad al-Ghazali is a controversial figure. Some give a positive appreciation to the method of hadith understanding he offered and regarded as a solutive method at the present day. But, other accused him as inkar al-sunnah and regarded his method was inapplicable. According to the author, some ideas of the reconstruction on the method of hadith understanding of Muhammad al-Ghazali still use a positivist paradigm that focuses on objectivity, while there are no objects without a subject. Therefore, in this paper, the author emphasizes the discussion on two points; first, criticizing the application of the method of hadith understanding of Muhammad al-Ghazali; and second, offering the new method of reconstruction using descriptive analysis and explanation method. The author examines the book of Muhammad al-Ghazali and other books that are the result of criticism of the researchers about him. The result, studying and understanding the hadiths requires a set of batiniyah in the form of consciousness and sincere intention, studying the authenticity of the hadith, structural and pragmatic analysis, and the reviewer must verify the results of intellectual activity comprehensively.
\end{abstract}

Abstrak: Muhammad al-Ghazali merupakan tokoh kontroversial. Ada yang memberikan apresiasi positif atas metode pemahaman hadis yang ditawarkannya yang dianggap solutif pada saat sekarang. Namun ada juga yang menuduhnya sebagai inkar al-sunnah dan menilai metode yang ditawarkannya belum aplikatif. Menurut penulis, beberapa tawaran rekonstruksi terhadap metode pemahaman hadis Muhammad al-Ghazali masih menggunakan paradigma positivisme yang menitikberatkan pada objektivitas, padahal tidak ada objek tanpa subjek. Dalam tulisan ini, penulis menekankan dua pembahasan, yakni: mengkritik aplikasi metode pemahaman hadis Muhammad al-Ghazali; dan menawarkan bentuk rekonstruksi metode yang baru dengan menggunakan metode analisis deskriptif dan penjelasan. Penulis mengkaji buku karya Muhammad al-Ghazali dan buku-buku lain yang merupakan hasil kritikan para peneliti terhadapnya. Hasilnya, di dalam mengkaji dan memahami hadis diperlukan seperangkat batiniyah berupa kesadaran dan niatyang ikhlas, mengkaji otentisitas hadis, analisis struktural dan pragmatik, dan pengkaji melakukan verifikasi terhadap hasil aktifitas intelektual (pemahaman) secara komprehensif.

Keywords: Muhammad al-Ghazali; niat dan kesadaran; otentisitas hadis; analisis struktural dan pragmatik; verifikasi pemahaman secara komprehensif 


\section{A. Pendahuluan}

Menjelang wafatnya, Rasulullah telah memberikan petunjuk kepada para pengikutnya tentang cara untuk melestarikan kelompok sosial yang telah dibangun. Petunjuknya berisi ketentuan agar berpegang pada al-Qur'an dan sunnah yang telah ditinggalkannya agar umat tidak sesat. ${ }^{1}$ Suatu kenyataan penting, bahwa wujud sumber ajaran yang sekarang bukan lagi dalam bentuk norma, melainkan sudah dalam bentuk praktik kehidupan sosial yaitu masyarakat Islam di Madinah. Menurut John Obert Voll dalam bukunya Islam Continuity and Change, bahwa masyarakat Islam di Madinah bukanlah gagasan utopis, melainkan suatu bentuk masyarakat yang konkret dan fungsional. Pada tahap ini, kehidupan sosial mereka menyatu dengan agama. ${ }^{2}$

Usaha memahami hadis merupakan suatu keharusan sebagai upaya awal untuk mengaktualisasikan dan mengamalkan hadis sebagai sumber ajaran Islam kedua setelah al-Qur'an dalam kehidupan sehari-hari. Hal ini penting untuk dilakukan karena hadis awalnya merupakan tradisi lisan yang hidup, longgar, dan fleksibel, kemudian menjadi tradisi tulis yang beku, kaku atau baku. Apalagi hadis-hadis yang menyangkut persoalan politik, sosial, ekonomi, dan budaya senantiasa memberikan celah kepada kita untuk melakukan kajian yang mendalam dan sekaligus pembaruan penafsiran, pemahaman, dan pemaknaan terhadapnya. Upaya tersebut mutlak dilakukan untuk memahami fenomena sosial-budaya sekarang ini. ${ }^{3}$ Bisa dilihat misalnya fenomena-fenomena: globalisasi, realitas virtual, ekonomi virtual, konsep tentang uang, McDonalisasi, masyarakat konsumer atau masyarakat jaringan adalah serentetan fenomena baru yang barangkali belum terpikirkan oleh para pemikir terdahulu. Untuk

\footnotetext{
'Imam Muslim, al-Jāmi' al-Ṣāḥịh, j. II (Surabaya: Salim Nabhan,), h. 198.

2Disarikan oleh Muslim A. Kadir, Ilmu Islam Terapan; Menggagas Paradigma Amali dalam Agama Islam (Yogyakarta: Pustaka Pelajar, 2003), h. 75.

3Peluang untuk memperoleh tujuan risalah Islam sebagai Rahmatan lil Alamin dialamatkan kepada semua umat manusia yang tidak membedakan ruang dan waktu. Persoalan pokok sesungguhnya tidak terletak pada peluang ini, melainkan pada pelaksanaan ajaran dan proses pencapaian tujuan. Unsur esensial yang harus menjadi pertimbangan umat saat ini adalah perbedaan ruang dan waktu mereka dengan masa Rasulullah. Sebagaimana yang telah dikonsepsikan oleh Sosiolog Karl R. Popper yang telah disarikan oleh Muslim Kadir bahwa perbedaan ruang dan waktu, terutama jika jaraknya menjadi semakin menjauh, akan mengakibatkan perbedaan dalam tatanan kehidupan dan permasalahan yang dihadapi. Lihat Karl R. Popper, The Open Society and Its Enemies (Princeton: Princeton University Press, 1950) dalam Muslim A. Kadir, Ilmu Islam Terapan ..., h. $159-160$
} 
membaca, memahami dan menjelaskan fenomena-fenomena sosial-budaya kontemporer yang sudah jauh berbeda dengan era sebelumnya, tidak cukup lagi mengandalkan paradigma lama. Oleh karena itu diperlukan ijtihad atau pemikiran yang keras untuk mencapai kemungkinan-kemungkinan penafsiran baru yang tetap sesuai dengan ruh dan jiwa keislaman dengan tetap memberikan kemungkinan-kemungkinan perluasan dan pengembangan wilayah pranata sosial budaya, politik, dan ekonomi yang sudah ada.

Muhammad al-Ghazali merupakan sosok ulama kontemporer yang hasil pemikirannya banyak menimbulkan pro dan kontra di kalangan para ulama', bahkan ada yang menuduhnya sebagai munkir al-sunnah. Akan tetapi banyak juga yang memberikan apresiasi positif, antara lain Quraish Shihab yang memandang bahwa hasil pemahaman Muhammad al-Ghazali terhadap hadis banyak memberikan solusi atas persoalan-persoalan yang terjadi sekarang baik terkait dengan metode maupun content hadis secara komprehensif. Walaupun demikian, sebaik apapun metode yang ditawarkan oleh seorang tokoh tentu masih memiliki kekurangan dan keterbatasan, termasuk metode pemahaman hadis Muhammad al-Ghazali yang masih belum applicable. Misalnya dalam memahami content hadis, langkah pertama yang dilakukan Muhammad alGhazali adalah menguji hadis itu dengan ayat al-Qur'an. Namun ia belum memberikan kaidah-kaidah operasionalnya, sementara itu ayat-ayat al-Qur'an bisa dipahami oleh siapa saja bahkan untuk tujuan yang negatif. Oleh karena itu masih diperlukan kajian kritis terkait dengan rekonstruksi aplikasi metode pemahaman hadis Muhammad al-Ghazali.

Ada dua hal yang dibahas dalam kajian kritis ini, yaitu konstruksi metode pemahaman hadis Muhammad al-Ghazali dan rekonstruksi terhadap aplikasi metode pemahaman hadisnya. Sebagai sumber datanya adalah buku-buku karya Muhammad Ghazali dan karya ulama maupun ilmuwan lain yang mengkritisi pemikirannya, serta buku-buku lain untuk mempertajam analisis. Untuk menghasilkan analisis kritis, penulis berusaha mengkajinya dengan menggunakan pendekatan multidisiplin dengan perangkat kerja ilmu hadis dan filsafat ilmu.

\section{B. Biografi Muhammad al-Ghazali}

Syaikh Muhammad al-Ghazali adalah seorang ulama terkenal kelahiran alBuhairah, Mesir, tepatnya di Nakla Inab, sebuah desa yang banyak melahirkan tokoh-tokoh Islam terkemuka pada zamannya. Dia lahir pada tanggal 22 Sep- 
tember 1917. ${ }^{4}$ Syaikh merupakan gelar kehormatan yang diberikan kepada orang-orang yang memiliki kualitas istimewa. Gelar syaikh sebenarnya sudah ada sejak zaman pra Islam. Dalam sejarah Islam, gelar syaikh diberikan kepada orangorang tertentu yang memiliki pengetahuan tentang ilmu-ilmu yang bersumber dari Kitab Suci. Gelar syaikh juga diberikan kepada pejabat yang mengurusi masalah agama, para pemuka aliran sufi, ilmuwan-ilmuwan di bidang al-Qur'an, ahli fiqih, para khatib, dan imam-imam shalat di masjid. ${ }^{5}$ Orang tuanya memilihkan nama Muhammad Ghazali karena rasa hormatnya dengan Hujjah alIslām Imam Abu Hamid al-Ghazali dan ketertarikannya terhadap dunia sufi.

Muhammad al-Ghazali memulai pendidikan dasarnya di Ma'had al-Dīn (sekolah agama yang berada di bawah naungan al-Azhar) di kota Alexandrea. Di sekolah ini dia berhasil menghafalkan al-Qur'an 30 juz di usia 10 tahun. Ia menamatkan Madrasah Ibtidaiyah pada tahun 1932. Kemudian ia menamatkan Madrasah Tsanawiyyah pada tahun 1937 di sekolah yang sama. Setelah itu, dia melanjutkan kuliah di Universitas al-Azhar fakultas Ushuluddin di Kairo. Di sana beliau menuntut ilmu dari beberapa ulama besar, antara lain: al-Zarqani, Syekh Mahmud Syaltut dan lain-lainnya. Muhammad Ghazali lulus dan mendapat gelar sarjana S.1 pada tahun 1941. Ia kemudian melanjutkan pendidikan S.2 di universitas yang sama. Meskipun Muhammad Ghazali aktif dalam kegiatan dakwah, dia tetap berusaha menyelesaikan pendidikan S.2-nya. Maka pada tahun 1943, ia berhasil mendapatkan gelar Magister Bahasa Arab. ${ }^{6}$

Ketika Muhammad Ghazali masih kuliah di Fakultas Ushuluddin, dia bertemu dengan Mursyid 'am Ikhwanul Muslimin Hasan al-Banna (1906-1949 M) yang akhirnya ia menjadi anggota organisasi tersebut. Muhammad Ghazali juga ikut merasakan cobaan dan cercaan yang menimpa organisasi Ikhwān alMuslimin sehingga sekitar tahun 1949 M pada masa Raja Faruq, ia ditahan dan

${ }^{4}$ Di antara tokoh-tokoh tersebut adalah Mahmud Sami al-Barudi, Syaikh Salim al-Bisyri, Syaikh Ibrahim Hamrusy, Syaikh Muhammad Abduh, Syaikh Mahmud Syaltut, Syaikh Hasan al-Banna, Muhammad al-Bahi, Syaikh Muhammad al-Madani, Syaikh Abdul al-Aziz Isa, dan Syaikh Abdullah alMusyid. Lebih lanjut lihat Suryadi, Metode Kontemporer Pemahaman Hadis Nabi Perspektif Muhammad al-Ghazali dan Yusuf al-Qardhawi (Yogyakarta: Teras, t.th.), h. 23-24, yang dikutip dari Abd al Halim 'Uwais, Al-Syaikh Muhammad al-Ghazali: Marahil 'Azimah fi Hayah Mujahid 'Azhim (Kairo: Dar al-Shahwah, 1993), h. 15.

5Lebih lanjut lihat John L. Esposito (eds.), "Shaykh", The Oxford Encyclopedia of the Modern Islamic World (New York: Oxford University Press, 1995) jilid IV, h. 52-53.

${ }^{6}$ John L. Esposito, Loc Cit. Lihat juga Abd al-Halim Uwais, al-Shaikh Muhammad al-Ghazāli: Marāḥil Aẓimah fi Hayah Mujāhid Aẓīm (Kairo: Dar al-Shahwah, 1993), h. 15. 
dipenjara di al-Thur (dataran tinggi Sinai). Ia kemudian dipindah ke penjara Thurah selama kurang dari satu tahun bertepatan dengan pemeriksaan bersama Sayyid Qutb yang syahid pada tahun 1965 pada masa Abdul Nashr.

Al-Ghazali adalah seorang ulama Islam yang sangat peduli terhadap persoalan-persoalan umat Islam kontemporer, terutama yang berhubungan dengan dakwah dan pemikiran. Aktivitasnya selama berada di Mesir antara lain: ia ditunjuk sebagai imam dan khatib di masjid al-Utba' al-Khadra Kairo (1943), menjabat sebagai Wakil Menteri Perwakafan untuk urusan dakwah (1981), namun akhirnya dipecat ketika berbeda pendapat dengan kebijakan negara mengenai perdamaian dengan Israel. Selain itu Muhammad Ghazali juga mengajar di Universitas al-Azhar. Sedangkan aktivitasnya di luar Mesir antara lain: memimpin majlis ilmiah di Universitas Amir Abdul Qadir al-Jazairi alIslamiyah di Aljazair selama 5 tahun, menjadi dosen di Universitas Ummul Qura di Mekkah Al-Mukaramah (1974-1981 M), menjadi Guru Besar di Fakultas Syari'ah Universitas Qatar. Di samping itu dia juga sering diundang untuk mengisi kegiatan agama kenegaraan di Kuwait dan seminar-seminar mahasiswa di Amerika maupun Eropa. ${ }^{7}$

Ia merupakan ulama yang produktif, banyak karya tulis yang telah dihasilkan. Tidak kurang dari 48 judul buku hasil karyanya telah diterbitkan dan diterjemahkan ke dalam berbagai bahasa asing, termasuk diterjemahkan ke dalam bahasa Indonesia. Bukunya yang menjadi best seller dan telah diterjemahkan ke dalam bahasa Indonesia adalah al-Sunnah al-Nabawiyyah Bayna Ahl alFiqh wa Ahl al-Hadith. Buku karya Al-Ghazali tersebut termasuk buku yang banyak diperbincangkan orang. Dari buku tersebut bisa diketahui bagaimana sikap intelektual al-Ghazali dalam menilai hadis Nabi, ia tidak terpaku pada persyaratan-persyaratan yang dibuat oleh ulama' hadis. Baginya ada yang lebih penting dari sekedar metode otentisitas hadis, yaitu mașlahat umat Islam (kepentingan umat Islam). ${ }^{8}$ Dia juga aktif menulis di berbagai majalah dan surat kabar berbahasa Arab.

7Sahiron Syamsuddin, Hermeneutika al-Qur'an \& Hadis (Yogyakarta: eLSAQ Press, 2010), h. 349-350, disarikan dari Yusuf Qardhawi, al-Syaikh al-Ghazali Kama Araftuhu; Rihlah Nishf al-Qarn (Kairo: Dar al-Wafa, 1995), h. 26.

8Badri Khaeruman, Otentisitas Hadis; Studi Kritis Atas Kajian Hadis Kontemporer (Bandung: Rosda Karya, 2004), h. 264. 
Karena jasanya dalam berdakwah bi '-lisān (melalui ceramah-ceramah) maupun bi 'l- qalam, maka Muhammad al-Ghazali mendapatkan penghargaan dari berbagai negara Islam. Pemerintah Aljazair pernah menganugerahinya "Bintang Jasa" sebagai penghargaan tertinggi pemerintah Aljazair untuk bidang dakwah Islam. Saudi Arabia menganugerahinya hadiah "Raja Faisal" dalam bidang yang sama. Muhammad al-Ghazali merupakan orang Mesir pertama yang mendapatkan penghargaan seperti itu. Pada tahun 1988, pemerintah Mesir menganugerahinya "Bintang Republik", ini merupakan penghargaan tertinggi untuk warga Mesir yang dinilai telah berjasa untuk kemanusiaan. Anugerah yang sama juga diperoleh dari Kerajaan Maroko dan Brunei Darussalam.

Muhammad Ghazali kembali ke Mesir dan menetap di rumahnya (Kairo) sejak tahun 1988 M. Beberapa bulan menjelang akhir hayatnya, ia masih sempat mengunjungi Amerika Serikat mewakili markas Penelitian Ilmu-ilmu Keislaman di Mesir dan menghadiri acara PBB pada tahun 1996 M. Saat itu beliau berceramah pada ulang tahunnya yang ke-80 sebagai perwakilan al-Azhar. Setelah beberapa minggu dari kedatangannya, dia pergi ke Saudi Arabia atas undangan Kerajaan untuk mengikuti pameran kebudayaan nasional ke-11 yang diadakan di Riyadh. Ketika menghadiri pameran tersebut, dia meninggal dunia di Aula Raja Faisal akibat serangan jantung kronis dan pembekuan darah yang sudah lama dideritanya pada hari Sabtu 19 Syawwal $1416 \mathrm{H}$ yang bertepatan dengan tanggal 9/ 8 Maret 1996 M. Ia meninggal pada usia 80 tahun. Jenazahnya kemudian diterbangkan dan dimakamkan di Mesir. ${ }^{9}$

\section{Pentingnya Rekonstruksi}

Rekonstruksi memiliki makna pembangunan kembali. Secara operasional rekonstruksi di sini dimaksudkan bahwa konsep-konsep pemahaman hadis dibangun kembali dan dilakukan tinjauan kritis terhadap beberapa konsep yang

${ }^{9}$ Sahiron Syamsuddin, Hermeneutika al-Qur'an \& Hadis, h. 350. Nampaknya terdapat informasi yang berbeda, menurut Yusuf Qardhawi, sudah sejak lama Muhammad Ghazali ingin mendapatkan tempat yang dekat dengan Nabi saw. Kematiannya di Saudi Arabia itu telah mengantarkannya ke pekuburan Baqi, dan itu hanya beberapa meter dari makam Rasulullah. Menurut Dr. Muhammad Umar Zubair, sahabat Yusuf Qardhawi yang sempat menghadiri upacara pemakaman Muhammad Ghazali , bahwa makamnya persis di antara kuburan Imam Malik (pendiri madzhab Maliki) dan Imam Nafi' (ahli Hadis). Lebih lanjut bandingkan Badri Khaeruman, Otentisitas Hadis; Studi Kritis Atas Kajian Hadis Kontemporer (Bandung: Rosda Karya, 2004), h. 270. 
dianggap bermasalah, yakni dengan menawarkan beberapa konsep yang merupakan modifikasi dari beberapa konsep yang sudah ada. ${ }^{10}$ Ada istilah yang hampir sama yakni Konstruktivisme adalah paradigma ilmiah yang berpendapat bahwa ilmu pengetahuan dan kebudayaan merupakan hasil konstruksi (aktivitas sosial-budaya) dan bukan yang terberi (given). ${ }^{11}$

Hadis sebagai sumber ajaran Islam kedua setelah al-Qur'an memiliki posisi yang penting dalam memahami Islam. Menurut Jumhur, sunnah/hadis Nabi adalah segala yang disandarkan kepada Nabi baik perkataan, perbuatan, ketetapan, sifat khalqiyyah (yang berhubungan dengan fisik) dan sifat khuluqiyyah (yang berhubungan dengan akhlak).

Berangkat dari realitas historis terjadinya transmisi hadis ke dalam teksteks hadis, ${ }^{12}$ yakni: 1) sunnah/hadis sebagai bentuk ideal teladan Nabi yang harus diikuti, telah ditrasmisikan dalam wacana verbal berupa laporan sahabat tentang Nabi kepada generasi semasa atau sesudahnya; 2) umat Islam dalam meneladani Nabi merujuk dari teks-teks hadis, ${ }^{13}$ sementara Nabi tidak pernah memberikan teks-teks hadis dan pemahamannya dalam bentuk baku untuk diteladani; 3) teks-teks hadis juga memuat tradisi praktikal dan verbal para sahabat dan generasi awal Islam yang dianggap merujuk dari teladan Nabi sebelum terkodifikasi ke dalam kitab-kitab hadis; 4) masuknya interpretasi dan adanya perbedaan pemahaman hadis yang dipengaruhi perbedaan metode, latar belakang syarih hadis, perbedaan dalam melihat fungsi dan kedudukan Nabi, dan perbedaan dalam melihat fungsi hadis dikaitkan dengan al-Qur'an. Maka umat Islam dituntut bersikap kritis dalam memahami teladan ideal. Apalagi ditambah dengan beberapa realitas yang lain, ${ }^{14}$ meliputi: 1) tidak seluruh hadis tertulis pada masa Nabi Muhammad., 2) telah timbul pemalsuan 140.

${ }^{10}$ A. Mansyur dkk., Metodologi Penelitian Living Qur'an \& Hadis (Yogyakarta: Teras, 2007), h. 207.

${ }^{11}$ Akhyar Lubis, Postmodernisme Teori dan Metode (Jakarta: RajaGrafindo Persada, 2014), h.

12Komaruddin Hidayat, Memahami Bahasa Agama: Sebuah Kajian Hermeneutik (Jakarta, Paramadina, 1996), h. 17. Lihat juga Musahadi Ham, Evolusi Konsep Sunnah Implikasinya pada Perkembangan Hukum Islam (Semarang: Aneka Ilmu, 2000), h. 120-124.

${ }^{13}$ Sebagaimana teks-teks yang lain, teks hadis tidak bisa mempresentasikan seluruh realitas teladan Nabi yang dinamis dan kompleks secara utuh. Begitu realitas diverbalkan dalam bentuk tulisan, maka akan terjadi penyempitan, distorsi dan pengeringan makna. Hal ini disebabkan karena keterlibatan rawi sebagai transmitter hadis dan historisitas yang melingkupinya.

${ }^{14}$ Syuhudi Ismail, Metodologi Penelitian Hadis Nabi (Jakarta: Bulan Bintang, 1992), h. 11-21. 
hadis, 3) rentang yang panjang dalam proses penghimpunan hadis, 4) jumlah kitab hadis dan metode yang beragam, 5) terjadinya periwayatan bi 'l-ma'nā, dan 6) tidak seluruh periwayatan hadis bersifat mutawatir sebagaimana al-Qur'an. Realitas tersebut penting untuk diketahui karena merupakan problem yang paling krusial dalam memahami otentisitas hadis Nabi. Hilangnya kesadaran sejarah transmisi hadis ke dalam teks-teks hadis telah mengimbas kepada adanya dogmatisasi teks-teks hadis dan pemahaman terhadapnya sebagai suatu yang normatif, ilāhiyyah, transendental, statis, final, dengan kesakralan dan keabadian maknanya. Bahkan, menganggap tidak ada lagi orang yang memiliki otoritas dan kapabilitas sebagaimana yang dimiliki para ulama' mutaqaddimin. ${ }^{15}$

Dalam kajian hadis secara konvensional, relasi antara teks dan author menjadi tema pokok yang mendapat porsi perhatian. Begitu sebuah teks hadis muncul, maka para ulama hadis segera memverifikasinya, apakah sang pengarang (author) dari teks itu benar-benar Nabi atau orang lain. Bila hasil verifikasi menunjukkan teks datang dari Nabi, maka segera mereka labeli dengan hadis sahịh. ${ }^{16}$ Sebaliknya, jika setelah diverifikasi ternyata teks tidak datang dari Nabi, maka mereka segera melabelinya dengan hadis ḍ̂̃̂f bahkan palsu. Jika meragukan, maka dilabeli sebagai hadis hasan. Bila mencapai akumulasi tertentu dapat dianggap sebagai hadis șậị li ghairihi. ${ }^{17}$

Sedangkan dalam kajian hadis kontemporer, yang lebih menjadi pokok bahasan adalah relasi antara teks dan reader (pembaca). ${ }^{18}$ Di sini eksistensi

${ }^{15}$ Lihat M. Mansyur dkk, Metodologi Penelitian Living Qur'an dan Hadis, h. 136-137.

16Bandingkan dengan pendapat Mahmud Thahhan, tidak setiap peneliti hadis pada umumnya mampu menjelaskan ada dan tidaknya illat maupun shadh, karena itu suatu perbuatan yang sangat sulit. Oleh karena itu orang yang telah meneliti sanad hadis sebaiknya mengatakan: sahihul isnad/ hasan al-isnad/dâîf al-isnad ketika menentukan nilai hadis yang ditelitinya. Mereka tidak dibenarkan langsung mengatakan hadis itu șahịh/ḥasan. Karena mereka masih harus mempertimbangkan kemungkinan terdapat hadis lain yang pengertiannya bertentangan dengan hadis yang telah ditentukan nilainya tersebut, sementara sanad hadis lain lebih kuat. Hal itu berarti hadis yang telah dinilai tersebut mempunyai 'illat dan shadh yang samar. Demikian juga dalam menentukan nilai hadis da'îf, mungkin sekali terdapat shāhid atau tabi' yang menguatkannya. Sehingga hadis yang telah dinilai ḍ̂îf tersebut dapat meningkat menjadi hadis hadīs șahīh li ghairihi. Lebih lanjut lihat Mahmud al-Tahhan, Ușūl al-Takhrïj wa-Dirāsat al-Asānid, terj. Ridlwan Nasir, Metode Tahrij dan Penelitian Sanad Hadis (Surabaya: Bina Ilmu, 1995). h. 153-154.

${ }^{17}$ Saifuddin Zuhri Qudsy dan Ali Imran, Model-model Penelitian Hadis Kontemporer (Yogyakarta: Pustaka Pelajar, 2013), h. xvii-xviii.

${ }^{18}$ Ada beberapa karakteristik metodologi penafsiran kontemporer: 1) tema kontekstual, 2) bentuk tidak utuh/ per tema (sesuai dengan kebutuhan), 3) metode: tematik-kontekstual, 4) pendekatan: hermeneutik, fenomenologi, 5) hasil: applicable meaning, 6) paradigma: kritik-partisipatoris-solutif, 7) irfani. Lihat Fatih Suryadilaga, Metodologi Syarah Hadis (Yogyakarta: Suka Press, 
pembaca mulai diperhitungkan sebagai subjek yang aktif memproduksi makna atas teks yang telah diserapnya. Bukan berarti problem otentisitas sudah tidak penting lagi di sini, hanya saja jika berhenti pada problem otentisitas, maka akan menimbulkan konsekuensi serius. Pertama, unsur makna atau pesan inti yang hendak disampaikan oleh teks tersebut menjadi tersubordinasi, termarginalisasi, dan tersisih. Kedua, keterpakuan pada teks juga akan memarginalisasikan reader (pembaca). Di sini persepsi reader terhadap idola (sosok pribadi yang disebut ulama) sedikit banyak mempengaruhi pemahaman atau interpretasi yang dimiliki reader tersebut. Bila antara reader dan idola (yang menjadi author teks) terdapat jarak waktu yang panjang, maka reader akan mencari atau menciptakan pseudo idol yang dianggap sebagai sosok yang sukses mengamalkan petunjuk idola sejati, yakni si author tersebut. Gejala-gejala tersebut tidak akan mampu dianalisis jika hanya menggunakan perangkat keilmuan hadis konvensional yang lebih menekankan aspek otentisitas, sementara perkembangan peradaban dan ilmu pengetahuan manusia sudah sangat pesat berkembang. ${ }^{19}$

Kajian hadis selama ini tidak beranjak dari kajian apakah teks-teks hadis yang ada otentik dari Nabi atau tidak; Rasul berperan sebagai apa dalam sabdasabdanya, sebagai manusia biasa, pribadi, suami, utusan Allah, kepala negara, pemimpin masyarakat, panglima perang ataukah sebagai hakim; serta apa yang menjadi sebab wurud teks hadis tersebut? Beberapa pertanyaan tersebut pada dasarnya dalam rangka mendudukkan pemahaman hadis pada tempat yang proporsional. Kapan hadis perlu dipahami secara tekstual, kontekstual, universal, temporal, situasional maupun lokal, karena pemahaman yang kaku, radikal dan statis sama artinya telah menutup keberadaan Islam yang șālị̣ li kulli zamān wa makān.

cet. 1, 2012), h. xx. Walaupun demikian, ada juga ulama hadis yang hidup di era kontemporer, namun kecenderungannya dalam memahami hadis secara tekstual-lahiriyah, misalnya Nashiruddin Albani. Dia memahami hadis berdasarkan apa yang tersurat dalam teks, bukan apa yang tersirat dibalik teks. Misalnya: "Barangsiapa yang shalatnya tidak mencegahnya dari perbuatan-perbuatan keji dan munkar, maka ia tidak menambah sesuatu pun dari Allah kecuali menjauh". Menurut Albani, secara lahiriyah hadis ini bertentangan dengan syariat dan tidak masuk akal. Sebab ia mencakup siapa saja yang mendirikan shalat dengan memenuhi syarat rukunnya. Sedangkan syariat tetap menghukuminya sebagai benar atau sah, walaupun pelaku shalat tersebut masih suka maksiat. Jadi tidak benar bahwa shalat yang sah justru akan semakin menjauhkan pelakunya dari Allah SWT. Ini adalah sesuatu yang tidak masuk akal dan bertentangan dengan syariat. Demikian menurut Albani. Lebih lanjut lihat Albani, Silsilah Hadis Dla'if dan Maudlu', terj. A.M. Basamalah Oakarta: Gema Insani Press, jilid I, 1997), h. 35-36. Berangkat dari keaneragaman pendekatan yang digunakan dalam memahami teks saat sekarang, maka yang dimaksud "kontemporer" dalam paper ini adalah cara pemahaman seseorang terhadap teks, bukan era (zaman).

${ }^{19}$ Saifuddin Zuhri, Ali Imran, Model-model Penelitian..., h. xvii-xviii.

JURNAL THEOLOGIA — Volume 28, Nomor 1, Juni 2017 
Kenyataan lain bahwa globalisasi dan hadis merupakan dua entitas yang berbeda baik geneologis, fungsi, maupun karakternya, namun umat Islam harus mempertahankan hadis dan menghadapi globalisasi. Oleh sebab itu umat Islam sebagai generasi penerus yang bertanggung jawab atas eksistensi dan kontinuitas hadis dituntut untuk senantiasa melakukan reformasi internal (self reformation) dalam memahami, menggunakan, dan mengaplikasikan hadis dalam kehidupan saat ini. ${ }^{20}$ Hadis tidak hanya cukup dipahami sebagai doktrin final dan tradisi yang tidak memiliki arti apapun, akan tetapi dipahami sebagai salah satu unsur penting dalam proses kehidupan umat Islam sesuai dengan konteks masyarakatnya. Oleh karena itu dalam memahami dan menginterpretasikan hadis, diperlukan metode yang tepat dengan memperhatikan karakter teks maupun kekhasan readernya. Terdapat beberapa metode yang sering digunakan dalam ilmu sosial-budaya, ${ }^{21}$ yaitu metode hermeneutika dan fenomenologi serta varian-variannya seperti: analisis wacana, analisis narasi, storytelling, semiotika, dekonstruksi, etnometodologi, etnografi, studi kasus kualitatif, genealogi, dan lain sebagainya.

\section{Kritik terhadap Konstruksi Metode Pemahaman Hadis Muhammad al-Ghazali}

Salah satu ulama kebangkitan Islam di Mesir yang membela eksistensi Sunnah di samping al-Qur'an adalah Muhammad al-Ghazali. Dia adalah sosok ulama yang kontroversial. Dalam rangka pembelaannya terhadap Sunnah (Hadis) Nabi Muhammad, Muhammad al-Ghazali menulis buku al-Sunnah alNabawiyyah bayna Ahl al-Fiqh wa Ahl al-Hadith. Tema-tema sentral dalam diskusi Muslim modern tentang hubungan antara al-Qur'an dengan Hadis, posisi otoritas Nabi Muhammad. dalam memutuskan hukum, dan metode kritik hadis, banyak dijelaskan di dalam bukunya tersebut. ${ }^{22}$

\footnotetext{
${ }^{20}$ Lebih lanjut lihat Barmawi Mukri, Kontekstualitas Hadis Rasulullah: Mengungkap Akar dan Implementasinya (Yogyakarta: Ideal Press, 2005), h. viii-xiii.

${ }^{21}$ Kajian sosial-budaya (humaniora) menolak asumsi keseragaman fenomena, kajian sosial budaya mengakui adanya keunikan individu dan kekhasan fenomena sosial-budaya. Oleh karena itu diperlukan paradigma interpretatif, kritis, dan konstruktivis yang menghargai keaneragaman dan keunikan fenomena sosial-budaya. Lebih lanjut lihat Akhyar Yusuf Lubis, Filsafat Ilmu Klasik Hingga Kontemporer (Jakarta: RajaGrafindo Persada, 2015), h.160-180.

${ }^{22}$ Daniel W. Brown, Menyoal Relevansi Sunnah dalam Islam Modern, terj. Jaziar Radianti \& Entin Sriani (Bandung: Mizan, 2000), h. 138.
} 
Masih di bukunya tersebut, Muhammad al-Ghazali juga menegaskan tentang pentingnya kerjasama antara ahl al-hadith dan ahl al-fiqh. Menurutnya, tugas ahl al-hadith adalah mengumpulkan hadis-hadis dan memperhatikan kualitas sanad dan matannya. Sedangkan tugas ahl al-fiqh adalah menyempurnakan tugas ahl al-hadith dengan mengetahui cacat yang tersembunyi dalam matan, menentukan isi, semangat, dan relevansi matan hadis dalam konteks syari'ah secara keseluruhan. ${ }^{23}$

Menurut Muhammad Ghazali, tegaknya Islam dapat terwujud dengan cara memahami dan menafsirkan kandungan al-Qur'an termasuk hadis dan berusaha merealisasikan tujuan serta pesan-pesannya. Ghazali menyatakan bahwa tidak ada fiqh kecuali dengan sunnah, dan tidak ada sunnah tanpa fiqh. Hukum agama tidak diambil dari satu hadis yang terpisah dengan hadis yang lain. Ia diambil dengan mengumpulkan hadis-hadis, kemudian membandingkan kumpulan hadis tersebut dengan al-Qur'an. Sesungguhnya al-Qur'an adalah bingkai semua hadis yang berjalan di dalamnya, dan hukum-hukum dalam hadis tidak berseberangan dengan hukum-hukum al-Qur'an, karena hukum-hukum dalam hadis șahịh diambil dan digali dari al-Qur'an. Rasulullah mengambil hukum tersebut dengan bimbingan Ilāhiyyah dan keterangan Rabbani untuk menafsirkan apa-apa yang disebutkan secara global dalam al-Qur'an. ${ }^{24}$

Secara sederhana dan sistematis, konstruksi metode pemahaman hadis Muhammad al-Ghazali mensyaratkan adanya 5 kriteria keshahihan hadis. Tiga hal terkait dengan sanad dan dua kriteria terkait dengan matan. Tiga kriteria keshahihan sanad hadis, meliputi: 1) Perawi harus d̦ābit, 2) Perawi harus adil, 3) Kriteria perawi ḍa bit dan adil harus dimiliki oleh seluruh perawi dalam sanad. Sedangkan untuk keshahihan matan ada 2 kriteria, meliputi: 1) Matan hadis tidak shadh yaitu periwayatan seorang rawi atau lebih tidak bertentangan dengan al-Qur'an dan rawi lain yang lebih akurat dan lebih dapat dipercaya. 2) Matan tidak mengandung 'illat qadihah (suatu sebab atau alasan yang mengakibatkan tertolaknya suatu hadis). ${ }^{25}$

${ }^{23}$ Muhammad al-Ghazali, al-Sunnah al-Nabawiyyah bayna Ahl al-Fiqh wa Ahl al-Hadith (Kairo: Dar al-Syuruq, 1989), h. 19-21.

${ }^{24}$ Ibid., h. 197.

25Ibid., h. 14-15.

JURNAL THEOLOGIA — Volume 28, Nomor 1, Juni 2017 
Suryadi telah melakukan pengkajian terhadap metode pemahaman hadis Muhammad al-Ghazali, ia menfokuskan karya al-Ghazali yang berjudul alSunnah al-Nabawiyyah bayna Ahl al-Fiqh wa Ahl al-Hadith. Kemudian dia menyimpulkan bahwa tolok ukur yang dipakai Muhammad al-Ghazali dalam kritik matan secara garis besar melalui 4 metode, yaitu: 1) pengujian dengan al-Qur'an, 2) pengujian dengan hadis, 3) pengujian dengan fakta historis, dan 4) pengujian dengan kebenaran ilmiah. Dari 48 hadis yang diangkat oleh Muhammad alGhazali, dikategorikan menjadi lima, yaitu: 1) pengujian dengan al-Qur'an, Hadis, fakta historis dan kebenaran ilmiah, 2) pengujian dengan al-Qur'an, fakta historis dan kebenaran ilmiah, 3) pengujian dengan Hadis, fakta historis dan kebenaran ilmiah, 4) pengujian dengan fakta historis dan kebenaran ilmiah, dan 5) pengujian dengan kebenaran ilmiah. ${ }^{26}$

\section{Pengujian dengan al-Qur'an}

Maksudnya, setiap hadis harus dipahami dalam kerangka makna-makna yang ditunjukkan oleh al-Qur'an baik secara langsung terkait dengan makna lahiriyah al-Qur'an, maupun tidak langsung yang terkait dengan pesan-pesan, semangat, dan nilai-nilai yang dikandung dalam al-Qur'an, dengan cara menganalogkan (qiyās) yang didasarkan pada hukum-hukum al-Qur'an. ${ }^{27}$

Menurut Muhammad Ghazali, al-Qur'an merupakan sumber pertama dan utama dari pemikiran dan dakwah, sedangkan hadis adalah sumber kedua. Dia berkeyakinan bahwa hadis merupakan sumber otoritatif setelah al-Qur'an. Akan tetapi tidak semua hadis orisinal dapat dipahami secara benar oleh periwayatnya. ${ }^{28}$ Maka oleh Muhammad al-Ghazali pengujian dengan ayat-ayat al-Qur'an mendapat porsi terbesar dibanding tiga tolok ukur lainnya. ${ }^{29}$

\footnotetext{
${ }^{26}$ Lihat Suryadi, Metode Kontemporer Pemahaman Hadis Nabi: Perspektif Muhammad alGhazali dan Yusufal-Qardhawi (Yogyakarta: Teras, 2008), h. 82-86.

${ }^{27}$ Ibid., h. 83-84.

${ }^{28}$ Karena lupa bisa terjadi pada siapapun termasuk sahabat, lupa merupakan salah satu potensi manusia. Aisyah istri Nabi telah mengkritik Umar dan anaknya Abdullah terkait dengan periwayatan keduanya tentang hadis yang berbunyi: إن الميت ليعنب ببكاء الحي , kemudian Aisyah

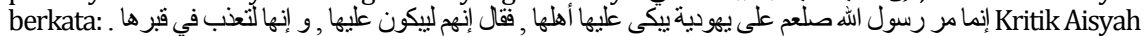
terhadap Umar dan Abdullah ibn Umar disebabkan karena kandungan hadis yang diriwayatkan itu bertentangan dengan apa yang ada dalam al-Qur'an bahwa setiap pribadi akan dimintai pertanggungjawaban atas perbuatannya di dunia. Hadis Umar dan anaknya Abdullah terkait dengan sebab khusus ketika Rasul melewati pekuburan orang Yahudi, namun kemudian berubah maknanya menjadi umum. Atas kasus ini Aisyah tidak meragukan keadilan Umar dan anaknnya Abdullah,
} 
Pengujian al-Qur'an dijalankan secara konsisten oleh Muhammad alGhazali dalam melakukan kritik hadis, sehingga tidak sedikit hadis-hadis yang dianggap șahịh oleh Bukhari maupun Muslim, namun dipandang dâîf oleh Muhammad al-Ghazali. Ia juga mengecam orang yang memahami dan mengamalkan secara tekstual hadis-hadis yang șaḥịh sanadnya, namun matannya bertentangan dengan al-Qur'an. Bahkan secara tegas dia mengatakan bahwa dalam hal-hal yang berkaitan dengan persoalan kemaslahatan dan muamalah dunyawiyyah, ia mengutamakan hadis yang sanadnya ḍaîf jika kandungan maknanya sesuai dengan prinsip-prinsip ajaran al-Qur'an, daripada hadis yang sanadnya șahịh akan tetapi kandungan maknanya tidak sesuai dengan inti ajaran al-Qur'an.

Penolakan Muhammad al-Ghazali terhadap sunnah yang dinilainya bertentangan dengan ayat-ayat al-Qur'an telah menimbulkan pro dan kontra. Bahkan ada yang menuduhnya sebagai inkār al-sunnah Namun bagi Muhammad al-Ghazali, apa yang dilakukannya itu justru merupakan pembelaan terhadap sunnah Nabi Muhammad. ${ }^{30}$ Bentuk-bentuk pembelaan sunnah sesungguhnya tidak terbatas pada pembuktian otentisitasnya, namun juga pemberian interpretasi-interpretasi yang sesuai. Inilah yang nampaknya diupayakan oleh Muhammad al-Ghazali dalam memahami hadis. Jadi Muhammad al-Ghazali menjadikan pengujian ayat-ayat al-Qur'an sebagai acuan utama, namun Ghazali belum memberikan kaidah maupun konsep yang aplikatif. Sementara itu, hasil pemahaman maupun interpretasi terhadap nash sangat subjektif tergantung siapa dan tujuannya apa?

Penolakan Ghazali terhadap hadis yang bertentangan dengan al-Qur'an ini memiliki akar sejarah dengan pemikiran yang berkembang sebelumnya (pada masa sahabat). Di antara sahabat saling mengkritik jika yang diriwayatkan memang dirasa ada kejanggalan sanad maupun matannya. Di sini Muhammad al-Ghazali mengakui telah terpengaruh istri Nabi Muhammad. Aisyah (w. $58 \mathrm{H}$ ) yang telah menolak hadis dari Umar dan Ibn Umar yang berbunyi:

namun Aisyah mengkritik bahwa keduanya telah lupa terkait dengan kasus tersebut Lebih lanjut lihat Muhammad Thahir al-Jawabi, Juhud al-Muhaddithīn fi Naqd Matn al Hadīth al-Nabawi al-Sharif (t.t.p.: Nasyr wa Tauzi' Muassasaat an al-Karim bin Abdullah, 1986), h. 460-462.

${ }^{29} \mathrm{Hal}$ itu juga sesuai dengan komentar M. Quraish Shihab yang terdapat di "Kata Pengantar" dalam Muhammad al-Ghazali, Studi Kritis atas Hadis Nabi saw Antara Pemahaman Tekstual dan Kontekstual, terj. Muhammad al-Baqir (Bandung: Mizan, 1996), h. 11.

${ }^{30}$ Muhammad Ghazali, Studi Kritis atas Hadis. 


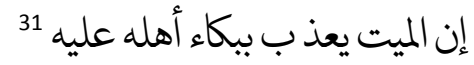

Aisyah kemudian menolak hadis yang telah diriwayatkan oleh keduanya tersebut karena bertentangan dengan QS. al-Fatir ayat 18 dan QS. al-An'am ayat 16432 yang artinya: "Dan seseorang tidak akan memikul beban dosa orang lain".

Bukan hanya Aisyah yang telah menolak hadis yang bertentangan dengan al-Qur'an, Umar bin Khathab (w. $23 \mathrm{H}$ ) juga telah menolak hadis tentang tidak adanya tunjangan dan tempat tinggal bagi wanita yang dicerai tiga oleh suaminya. Hadis yang dimaksud diriwayatkan oleh sahabat Fatimah binti Qais, kemudian ditolak Umar karena bertentangan dengan makna zōhir QS. al-Thalaq ayat $1 .{ }^{33}$

Untuk menguji kemudian memutuskan bahwa hadis tidak bertentangan dengan al-Qur'an merupakan proses yang tidak mudah dan tidak instan. Menurut penulis, dalam proses pengujian dibutuhkan ilmu, skill, kejernihan hati, dan kehati-hatian. Karena al-Qur'an merupakan kitab yang tidak sistematis susunannya, walaupun ketidaksistematisannya itu justru menjadikan kelebihannya sehingga al-Qur'an tidak akan usang. al-Qur'an bisa dipahami dan dipegangi oleh siapapun dan kapanpun umat itu ada, baik oleh kelompok yang kategorinya tekstualis, kontekstualis, maupun ekstrimis. Di samping susunan yang tidak sistematis, karakter ayat-ayat dan bahasa al-Qur'an adalah interpretable sehingga terbuka oleh siapapun dan kapanpun untuk bisa memahami dan memeganginya, ${ }^{34}$ bahkan oleh orang yang bertujuan tidak baik (merusak). Oleh

\footnotetext{
${ }^{31}$ Lebih lanjut lihat Muhammad al-Ghazali, al-Sunnah al-Nabawiyyah bayna Ahl al-Fiqh wa Ahl al-Hadith, h. 16-17.

32 . Lebih lanjut lihat Muhammad al-Ghazali, ibid.

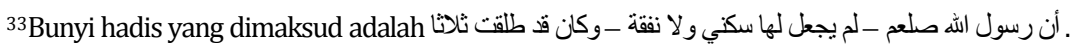
Hadis tersebut ditolak oleh Umar karena bertentangan dengan dhahirnya QS. al-Thalaq ayat 1: “.... janganlah kamu keluarkan mereka dari rumahnya dari rumahnya dan janganlah (diijinkan) keluar kecuali jika mereka mengerjakan perbuatan keji yang jelas ..." (QS. al-Thalaq: 1). Para fuqaha' berbeda pendapat dalam memahami hadis Fatimah binti Qais tersebut. Menurut ulama' Malikiyyah dan Syafi'iyyah bahwa istri yang ditolak tiga kali itu masih berhak tempat tinggal bukan nafkah. Dan Umar menyebutnya thalaq ruju' bukan țalāq ba'in, Umar menjadikan dhahirnya ayat sebagai sunnah yang diikuti. Lebih lanjut lihat Muhammad al-Ghazali, al-Sunnah al-Nabawiyyah..., h. 31-32.

${ }^{34}$ Sesungguhnya perbedaan dalam memahami hukum syariat termasuk al-Qur'an bukan suatu yang prinsip dan merupakan hal yang tidak bisa dihindari karena itu merupakan karakter agama, bahasa, manusia, keadaan, dan kehidupan. Lebih lanjut lihat Yusuf al-Qardhawi, al-Ṣahwah al-Islāmiyah bayna al-Ikhtilāf al-Mashru' wa al-Tafarruq al-Madhmūm (Kairo: Dār al-Shurūq, 2001), h. $42-49$.
} 
karenanya, dalam proses pengujian hadis terhadap al-Qur'an, menurut penulis perlu disyaratkan pentingnya meluruskan niat.

\section{Pengujian dengan Hadis}

Maksudnya matan hadis yang dijadikan dasar argumen tidak bertentangan dengan hadis mutawatir dan hadis lainnya yang lebih șahịh, yang dalam ilmu hadis pembahasan ini terkait dengan persoalan shadh. Menurut Imam Syafi'i sebuah hadis dikatakan shadh jika riwayat hadis yang disampaikan oleh perawi yang thiqah bertentangan dengan periwayatan sejumlah perawi yang thiqah juga. ${ }^{35}$ Menurut Muhammad al-Ghazali bahwa setiap hadis harus dikaitkan dengan hadis lainnya. Termasuk dalam memutuskan hukum yang berdasarkan agama, maka hadis yang dijadikan dasar pengambilan hukum tidak boleh terpisah dengan hadis lain. Kemudian hadis-hadis yang tergabung itu dikomparasikan dengan apa yang ditunjukkan oleh al-Qur'an. ${ }^{36}$

Muhammad al-Ghazali menyatakan bahwa tegaknya Islam dapat terwujud dengan cara memahami dan menafsirkan kandungan al-Qur'an termasuk hadis dan berusaha merealisasikan tujuan serta pesan-pesannya. Ghazali menyatakan bahwa tidak ada fiqh kecuali dengan sunnah, dan tidak ada sunnah tanpa fiqh ${ }^{37}$ Hukum agama tidak diambil dari satu hadis yang terpisah dengan hadis yang lain. Namun diambil dengan mengumpulkan hadis-hadis, kemudian membandingkan kumpulan hadis tersebut dengan al-Qur'an. Sesungguhnya alQur'an adalah bingkai semua hadis yang berjalan di dalamnya, dan hukumhukum dalam hadis tidak berseberangan dengan hukum-hukum al-Qur'an. Karena hukum-hukum dalam hadis șahịh diambil dan digali dari al-Qur'an. Rasulullah saw. mengambil hukum tersebut dengan bimbingan Ilāhiyyah dan keterangan Rabbani untuk menafsirkan apa-apa yang disebutkan secara global dalam al-Qur'an. ${ }^{38}$

Dari penjelasan tersebut nampaknya Ghazali cenderung memahami hadis secara komprehensif, karena satu hadis bisa saja menjadi sebab wurud hadis

\footnotetext{
${ }^{35} \mathrm{Ibn}$ al-Ṣalāh dalam bukunya Ulum al-Hadits yang telah disarikan oleh Suryadi, Metode Kontemporer...., h. 85.

36Muhammad al-Ghazali, al-Sunnah al-Nabawiyyah..., h. 142.

37 Ibid., h. 24-25.

38Ibid., h. 142-143.
}

JURNAL THEOLOGIA — Volume 28, Nomor 1, Juni 2017 
yang lain. Oleh karena itu menurut Muhammad al-Ghazali, pemahaman hadis secara parsial tidak dibenarkan. Klaim ini didasarkan pada realitas historis metode pengajaran Rasul kepada para sahabat yang dilakukan secara bertahap. al-Qur'an juga menempuh cara bertahap dalam menentang akidah-akidah rusak dan tradisi-tradisi berbahaya serta memberantas segala bentuk kemungkaran yang dilakukan oleh manusia pada masa pra Islam (Jahiliyyah). Bahkan, alQur'an juga menempuh cara bertahap dalam menancapkan akidah yang benar, ibadah, hukum, ajaran etika luhur dalam membangkitkan keberanian orangorang yang berada di sekitar Nabi Muhammad. agar selalu bersabar dan teguh hati. Dalam hal ini Rasul menjelaskan al-Qur'an, memberikan fatwa, melerai pihak-pihak yang bersengketa, menegakkan hukuman dan mempraktekkan ajaran-ajaran al-Qur'an, semua itu merupakan sunnah. ${ }^{39}$ Menurut penulis, metode Muhammad al-Ghazali untuk memahami hadis secara komprehensif tersebut bisa membantu seseorang dalam memahami maksud dan makna hadis maupun ide moralnya.

\section{Pengujian dengan Fakta Historis}

Menurut Muhammad al-Ghazali hadis perlu dikonfirmasikan dengan kebenaran sejarah, karena suatu keniscayaan bahwa munculnya hadis dilatarbelakangi oleh historisitas tertentu, ${ }^{40}$ sehingga antara hadis dengan sejarah memiliki hubungan sinergis yang saling menguatkan satu sama lain. Adanya kecocokan antara hadis dengan fakta sejarah akan menjadikan hadis memiliki sandaran validitas yang kokoh, demikian juga sebaliknya. Oleh karena itu, jika terjadi penyimpangan antara hadis dengan sejarah maka salah satu dari keduanya diragukan kebenarannya.

\section{Pengujian dengan Kebenaran Ilmiah}

Hadis șahịh yang dapat diamalkan matannya adalah yang tidak bertentangan dengan teori ilmu pengetahuan. Jika sebaliknya, maka hadis tersebut tidak layak dipakai. Untuk mempraktikkan kriteria tersebut, maka Muhammad al-Ghazali menganggap perlu adanya dialog antara muhaddith dengan para ahli ilmu-ilmu yang lain, seperti: para fuqahō', mufassir, ahli ușūl maupun mu'āmalah

\footnotetext{
${ }^{39}$ Lebih lanjut lihat M. 'Ajjaj al-Khathib, Ushul al-Hadits; Pokok-pokok Ilmu Hadits, terj. HM. Qadirun dan Ahmad Musyafiq (Jakarta: Gaya Media Pratama, 1998), h. 49.

${ }^{40}$ Lebih lanjut lihat Suryadi, Metode Kontemporer ...., h. 205.
} 
sehingga perlu pengetahuan dari berbagai ahli. Bahkan menurut penulis termasuk ahli di bidang sains baik fisika, kimia, matematika, biologi, dan lainnya disesuaikan dengan content hadisnya. Karena tidak sedikit hadis-hadis sains yang butuh penjelasan dari ahlinya. Juga perlu didialogkan dengan ilmuwan sosial dan humaniora baik secara langsung (dalam kajian interdisipliner) maupun tidak lagsung (baik berupa pemikiran, konsep, dan teori-teorinya) yang disesuaikan dengan content hadis dan konteks reader-nya. Sampai di sini Muhammad Ghazali juga tidak memberikan penjelasan langkah-langkahnya secara konkret berupa tahapan-tahapan dalam memahami hadis Nabi Muhammad.

Di sisi lain, kebenaran bukanlah suatu esensi yang statis, kekal, transenden dan mendahului realitas. Kebenaran dipahami sebagai eksistensi yang berbeda stereotype sebagai peristiwa yang bermacam-macam pembacaan dan bentukbentuk penampakan maupun interpretasinya. Sebuah kebenaran hanya menjadi sistem eksperimen atau proses untuk menjelaskan dan menafsirkan sesuatu. Kebenaran merupakan pedoman prinsip, sistem aksioma, kerangka acuan untuk melihat sesuatu dan dasar pemikiran untuk meneliti. ${ }^{41}$ Oleh karena itu menurut penulis, pada tahap pengujian hadis dengan kebenaran ilmiah maka seseorang yang berusaha memahami maupun menginterpretasikan hadis penting untuk memahami: a) karakteristik hadis, misalnya apakah itu hadis sains, muamalah, atau akidah dan yang lainnya? b) Situasi maupun kondisi author, teks, dan reader, c) pada wilayah praksis, perlu dipertimbangkan berbagai implikasi positif maupun negatif yang terjadi sebagai hasil dari pemahaman, sehingga seseorang yang memahami hadis penting untuk memiliki wawasan yang luas dan memahami perkembangan pemikiran yang ada. ${ }^{42}$

Yusuf Qardhawi memberikan apresiasi terhadap pemikiran Muhammad alGhazali tentang metodenya dalam memahami hadis, sekaligus juga kritikan. Menurut Qardhawi, metode Ghazali belum aplikatif sehingga bisa memicu ke-

${ }^{41}$ Lebih lanjut lihat Ali Harb, Asilah al-Haqīqah wa Rahanat al-Fikr: Muqarahat Naqdiyyah wa Sijaliyyah, terj. Nalar Kritis Islam Kontemporer (Yogyakarta: IRCiSoD,), h. 186-189.

${ }^{42}$ Perkembangan teknologi informasi telah mengubah cara pandang kita tentang ilmu pengetahuan dan kebudayaan yang disebut dengan postmodern. Sejumlah pemikir postmodern memiliki pandangan bahwa ilmu pengetahuan selalu bersifat hermeneutis, kontekstual, dan perspektifis. Berbagai interpretasi selalu dilatarbelakangi oleh prasangka/ tradisi. Jadi, tidak ada metode yang memberi jaminan kebenaran final, termasuk metode empiris eksperimental juga tidak dapat memberikan jaminan itu. Kebenaran teori diakui dalam konteks bersifat tentatif dan bukan bersifat absolut dan universal. Lebih lanjut lihat Akhyar Yusuf Lubis, Filsafat Ilmu Klasik Hingga Kontemporer (Jakarta: Rajagrafindo Persada, 2015) h. 178-179. 
kaburan yang dikhawatirkan bisa memalingkan pemikiran sebagian dari pembacanya dari misi dasar yang dibawa olehnya. ${ }^{43}$ Apresiasi dan kritikan juga disampaikan oleh Suryadi bahwa tawaran metode pemahaman hadis dan aplikasinya yang dikemukakan Muhammad al-Ghazali telah memberikan cukup besar kontribusi dalam menjawab berbagai persoalan umat Islam saat ini. Namun Suryadi juga mengklaim bahwa masih ada kelemahan dan kekurangannya, yaitu: 1) Muhammad al-Ghazali menjadikan pengujian ayat-ayat al-Qur'an sebagai acuan utama, namun tidak menjelaskan konsep operasionalnya. 2) Tidak menjelaskan secara terperinci konsepnya tentang kriteria pengujian dengan hadis, fakta historis dan kebenaran ilmiah. Hal tersebut akan menyulitkan pengkaji dalam melakukan prosedur penelitian. 3) Tidak menerangkan aplikasi 4 kriteria tersebut di atas terhadap hadis yang dibahasnya. Dengan kata lain, tidak dijelaskan kapan 4 kriteria tersebut dipakai dan kapan hanya beberapa kriteria yang digunakan. Empat kriteria metode pengujian baik pengujian dengan al-Qur'an, hadis, fakta historis, dan kebenaran ilmiah yang ditawarkan Muhammad al-Ghazali lebih memungkinkan untuk diterapkan dalam satu hadis tertentu. ${ }^{44}$

Dengan memperhatikan kelebihan dan kekurangan baik metode dan aplikasi metode Muhammad al-Ghazali, Suryadi menawarkan perlunya langkahlangkah metodologis secara sistematis yang dikutip dari pemikiran Muhammad 'Abid al-Jabiri.45 Pertama, analisis strukturalis, ${ }^{46}$ yaitu dalam mengkaji hadis

43Yusuf Qardhawi, Bagaimana Memahami Hadis Nabi saw, terj. Muhammad al-Baqir (Bandung: Karisma, 1993), h. 5-7.

${ }^{44}$ Suryadi, Metode Kontemporer ..., h. 225-226.

${ }^{45}$ Ibid., h. 228.

${ }^{46}$ Hermeneutika Ricoeur menolak pendekatan strukturalisme yang memperlakukan bahasa sebagai sistem belaka. Bagi Recoeur, bahasa adalah wacana yang merupakan kesatuan semiotik (tanda) dan semantik (makna). Wacana mengacu pada konteks atau dunia di mana dan bagaimana ia dilukiskan, diungkapkan dan digambarkan. Recoeur mengkritik strukturalisme membentuk dikhotomi langue dengan parole. Langue adalah abstraksi (sistem, kode linguistik) di tingkat sosialbudaya, sedangkan parole adalah realisasi (ujaran)bahasa di tingkat individu. Linguistik (strukturalisme) mengutamakan langue, sedangkan hermeneutika memprioritaskan parole. Sedangkan langkah-langkah metode hermeneutika yang ditawarkan oleh Recoeur adalah: (1) distansiasi, (2) interpretasi, dan (3) apropriasi. Distansiasi merupakan proses otonomi teks dengan cara membedakan antara "penafsiran si penafsir" dengan "makna yang dimaksudkan si penulis" yang hasilnya dunia internal teks. Interpretasi dengan cara menelaah teks secara utuh melalui pendekatan fenomenologi maupun semiotik. Tujuan utama penafsiran bukan untuk menentukan mana yang paling benar, akan tetapi untuk memperkaya pemahaman dan memperluas wawasan yang hasilnya adalah kebenaran performatif. Apropriasi, maksudnya dalam menafsirkan teks penafsir mengambil jarak dari intensi penulis, sehingga penafsir atau pembaca harus mampu memahami sendiri teks 
harus berangkat dari teks-teks sebagaimana adanya. Ini berarti perlu meletakkan jenis pemahaman tentang persoalan-persoalan hadis tersebut serta dijadikan objek kajian dari tema hadis yang dimaksud. Dalam analisis ini ada jarak antara pembaca dengan teks, sehingga tercapai unsur objektivitas ${ }^{47}$ dalam membaca teks Nabi Muhammad. Kedua, analisis historis, yaitu adanya upaya mengembalikan watak kesejarahan teks hadis Nabi, yaitu dengan menempatkan dalam konteks sosial, politik, kultural, dan ideologisnya. Hal ini perlu mempertimbangkan adanya keharusan memahami historisitas dan generalisasi sebuah pemikiran yang sedang dikaji. Demikian juga mengharuskan adanya pengujian validitas-validitas secara jeli tentang apa saja yang dikatakan sebuah teks dan yang tidak, dan yang dikatakan namun didiamkan. Ketiga, kritik idiologi, yaitu mengungkap fungsi-fungsi ideologis, termasuk fungsi sosial politik yang dikandung sebuah teks, atau pemikiran tertentu yang sengaja dibebankan kepada teks tersebut dalam satu sistem pemikiran (episteme) tertentu yang menjadi rujukannya. Menurut Suryadi ketiga pendekatan tersebut harus dilakukan secara berurutan ketika melakukan pengkajian hadis Nabi dan bersifat objektif dan rasional. Objektivisme (maudhu'iyyah) berarti menjadikan tradisi lebih kontekstual dengan dirinya. Ini berarti memisahkan dirinya dengan kondisi kekinian kita. Sedangkan rasionalitas (ma'quliyyah) adalah menjadikan teks hadis tersebut lebih kontekstual dengan kondisi kekinian kita. ${ }^{48}$

\section{E. Tawaran Rekonstruksi Metode Pemahaman Hadis}

Dalam sejarah, para ulama hadis dari generasi mutaqaddimin sampai muta'akhkhirin telah menawarkan dan menggunakan metode tertentu dalam upaya memahami teladan Nabi (hadis). Beberapa ulama' hadis telah melakukan

secara kreatif sehingga menghasilkan transformasi yang kreatif. Apropriasi merupakan puncak interpretasi dimana dua horizon yaitu dunia teks dengan dunia pembaca/ penafsir ketemu. Lebih lanjut lihat Akhyar Yusuf Lubis, Filsafat Ilmu Klasik ..., h. 193-194

${ }^{47}$ Husserl menolak pandangan positivisme (objektivisme). Paradigma positivisme tidak mampu melihat kesadaran, makna hidup dan motivasi sebagai pemberi makna pada fakta fisis (tingkah laku). Objektivisme dipandang oleh Husserl telah mengabakan peran manusia (dimensi subjek) dalam menciptakan ilmu pengetahuan. Positivisme tidak mampu melihat manusia secara utuh dan rasional. Sementara objektivitas yang didambakan oleh positivisme merupakan hasil dari fungsi subjektif. Artinya apa yang disebut empiris atau subjektif itu ditentukan berdasarkan nilainilai yang telah ditentukan oleh subjek. Tidak ada objek(tivitas) tanpa subjek(tivitas), tidak ada objek tanpa subjek, demikian sebaliknya. Lebih lanjut lihat Akhyar Yusuf Lubis, Filsafat Ilmu Klasik ...., h. 208-209.

${ }^{48}$ Suryadi, Metode Kontemporer ..., h. 228. 
rekonstruksi pemahaman hadis terhadap konsep-konsep pokok/ global seperti yang dikemukakan oleh al-Khatib al-Baghdadi, ${ }^{49}$ Ibn al-Jauzi, ${ }^{50}$ Șalāh al-Dīn alAdabi, ${ }^{51}$ Yusuf al-Qardhawi, ${ }^{52}$ dan Fazlur Rahman, ${ }^{53}$ dan masih ada tokoh yang lainnya. Rekonstruksi metode yang ditawarkan para tokoh tersebut termasuk Muhammad al-Ghazali dalam mengkaji dan memahami hadis nampaknya belum memandang penafsir sebagai manusia yang utuh dan rasional, kemudian paradigma yang dipakainya adalah positivisme (objektivisme). Paradigma ini tidak mampu melihat kesadaran, makna hidup dan motivasi sebagai pemberi makna pada fakta fisis (tingkah laku). Padahal objektivisme menurut Husserl telah mengabaikan peran manusia (dimensi subjek) dalam menciptakan ilmu pengetahuan. Sementara objektivitas yang didambakan oleh positivisme merupakan hasil dari fungsi subjektif. Artinya apa yang disebut empiris atau subjektif itu ditentukan berdasarkan nilai-nilai yang telah ditentukan oleh subjek. Tidak ada objek(tivitas) tanpa subjek(tivitas), tidak ada objek tanpa subjek, demikian sebaliknya. Positivisme membatasi ilmu pengetahuan pada gejala fisis dan ini merupakan suatu reduksionisme. Persoalan yang terkait dengan eksistensi rasional, emosional, makna, dan tujuan hidup manusia di-

${ }^{49}$ Bahwa kriteria matan hadis maqbūl sejalan dengan: 1) akal sehat, 2) hukum al-Qur'an yang muhkam, 3) hadis mutawatir, 4) amalan ulama' salaf, 5) dalil yang pasti, 6) hadis ahad yang kualitas kesahihannya lebih tinggi. Lebih lanjut lihat Abu Bakr bin Ali Sabit al-Khatib al-Baghdadi, Kitāb alKifāyah fi Ilm al-Riwāyah (Mesir: Matba'ah al-Sa'adah, 19720), h. 206-207.

${ }^{50}$ Kriteria Hadis yang berkualitas adalah: 1) tidak bertentangan dengan akal, dan 2) tidak bertentangan dengan ketentuan pokok agama. Lihat Abu Farj Abd al-Rahman bin Ali bin al-Jauzi, Kitāb al-Maw ụūāt (Beirut: Dār al-Fikr, 1983), h. 108.

${ }^{51}$ Ada 4 tolok ukur kualitas hadis, meliputi: 1) tidak bertentangan dengan petunjuk al-Qur'an, 2) tidak bertentangan dengan Hadis yang lebih kuat, 3) tidak bertentangan dengan akal sehat, indra dan fakta sejarah, 4) susunan pernyataannya menunjukkan ciri-ciri sabda kenabian. Sebagian besar ulama' Hadis baik tekstualis maupun kontekstualis berpandangan demikian dalam memahami matan Hadis. Lihat Salah al-Din bin Ahmad al-Adlabi, Manhaj Naqd al-Matn (Beirut: Dār al-Afaq alJadīdah, 1983), h. 230.

${ }^{52}$ Dalam memahami hadis, Qardhawi menawarkan 8 kriteria: 1) berdasar petunjuk al-Qur'an, 2) pengumpulan hadis-hadis yang setema, 3) menggabungkan atau men-tarjih hadis yang kontradiktif, 4) mempertimbangkan setting dan latar belakang munculnya hadis dan tujuannya, 5) membedakan sarana yang berubah-ubah dan sarana yang tetap, 6) membedakan kapan yang hakiki dan kapan majazi, 7) membedakan alam gaib dan kasat mata, dan 8) memastikan makna dan konotasi dalam hadis.. Lebih lanjut lihat Yusuf Qardhawi, Kaifa Nata'amal ma'a al-Sunnah alNabawiyah, terj. Muhammad al-Baqir (Bandung: Karima, 1993), h. 93-183.

${ }^{53}$ Dalam memahami hadis Rahman menawarkan 1) pemahaman terhadap makna teks, 2) pemahaman terhadap latar belakang, dan 3) berdasar petunjuk al-Qur'an untuk dapat menangkap ide moral yang dituju. Lebih lanjut lihat Islamic Methodology in History (Karachi: Central Institute of Islamic Research, 1965), h. 81. 
lenyapkan karena menurut positivisme tidak dapat diverifikasi melalui metode ilmiah. $^{54}$

Sementara itu baik-buruknya perbuatan, besar-kecilnya hasil, dan sebagainya ditentukan oleh niat (kesadaran) seseorang. Sebagaimana pernyataan Rasulullah, bahwa seseorang akan mendapatkan sesuatu sesuai dengan niatnya. ${ }^{55}$ Senada dengan hal tersebut, menurut Yusuf Qardhawi bahwa asal mula setiap bid'ah maupun kesesatan yang lain yang timbul dalam Islam, bahkan setiap kekeliruan dalam ușūl maupun furū' karena pemahaman yang buruk berkenaan dengan al-Qur'an maupun hadis dan niat (motivasi) maupun kesadaran yang buruk. Hasil pemikiran dari seorang tokoh sudah baik, namun ketika seorang pengikut dalam mengaplikasikan pemikirannya memiliki niat yang buruk maka akan menghasilkan pemahaman yang buruk. ${ }^{56}$

Terkait dengan pemikiran tersebut, penulis menawarkan rekonstruksi metode pemahaman hadis: pertama, di dalam mengkaji dan memahami hadis dibutuhkan kesadaran dan niat yang ikhlas". Hal ini penting, karena epistemologi yang didasarkan pada al-Qur'an dan hadis itu disandarkan pada kekuatan spiritual dengan mengharmonisasikan wahyu, akal dan rasa. Di samping itu, epistemologi Islam juga menekankan pencarian semua bentuk ilmu pengetahuan dalam kerangka nilai-nilai abadi yang merupakan landasan utama peradaban Muslim. $^{57}$

Dalam pandangan Islam, akal berbeda dengan otak. Ia merupakan daya pikir yang terdapat dalam jiwa manusia. Akal dalam Islam merupakan tiga unsur, yaitu: pikiran, perasaan, dan kemauan (niat). Dalam pengertian, pikiran terdapat pada otak, perasaan terdapat pada indera, dan kemauan terdapat pada jiwa. Ketiga unsur akal tersebut, satu dengan yang lain tidak dapat dipisahkan. Apabila salah satunya terpisah maka tidak lagi berfungsi sebagai akal.

Oleh karena itu para pencari ilmu, lebih-lebih para pencari hadis (termasuk para syarih), hendaklah berhati-hati untuk tidak menjadikan pencarian hadis atau ilmu sebagai suatu batu loncatan dalam mencapai tujuan-tujuan duniawi.

${ }^{54}$ Akhyar Yusuf Lubis, Filsafat Ilmu Klasik ...., h. 208-209.

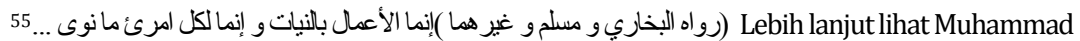
Abd al Aziz al-Khuli, al-Adab al-Nabawī (Beirut: Dar al-Kutub al-Ilmiah, 2005), h. 5-6.

${ }^{56}$ Lihat Yusuf Qardhawi, Bagaimana Memahami Hadis Nabi saw., h. 25-26.

${ }^{57}$ Ibid. 
Dijelaskan dalam sebuah hadis șahịh dari Abu Hurairah bahwa Rasulullah bersabda berkenaan dengan manusia yang pertamakali diadili pada hari kiamat:

$$
\begin{aligned}
& \text {... و وجل تعلّمَ العلم و علمّهه و قرأ القرأن فأوتي به فعرّفه نِعمَه فعرفها قال: فما }
\end{aligned}
$$

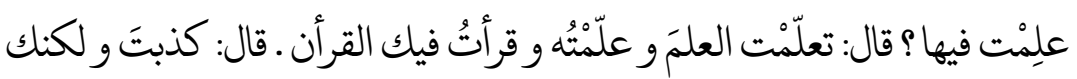

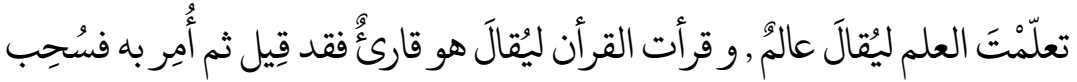

$$
\begin{aligned}
& \text { على وجهه حتى كُبّ في النار . أخرجه مسلم } 58
\end{aligned}
$$

... Dan seseorang yang belajar dan mengajarkan ilmu dan membaca alQur'an, maka dia dihadapkan kepada Allah Yang Maha Adil. Lalu Allah menunjukkan kepadanya kenikmatan-kenikmatan-Nya dan ia pun mengenalnya. Allah berkata, "Apabila yang kamu kerjakan untuk mendapatkannya?" Ia berkata, "Aku belajar dan mengajarkan ilmu, dan aku membaca Al Qur'an demi Engkau." Allah berkata, "Bohong kamu! Kamu mempelajari ilmu supaya dijuluki sebagai orang yang berilmu, dan kamu membaca Al Qur'an supaya dijuluki sebagai qari', dan julukan itu telah kamu terima." Kemudian diperintahkan agar ia diseret dan dijerumuskan ke dalam neraka. (Diriwayatkan oleh Imam Muslim).

Pentingnya seperangkat batiniyah yang mendukung para pengkaji hadis berupa kesadaran dan niat yang ikhlas juga diinspirasikan dari Ruhaili dalam bukunya Manhajiyah Fiqh al Sunnah al Nabawiyah. Di dalam buku tersebut dinyatakan bahwa ada lima alat maupun perlengkapan dalam memahami agama (termasuk hadis, pen). Seseorang tidak akan mungkin mengimplementasikan dan mengaplikasikan agama secara sahih (benar) kecuali dengan lima hal sebagai berikut: 1) ikhlas, 2) nash syar'i, 3) pemahaman nash syar'i, 4) akhlak yang baik, dan 5) aplikasi dan implementasi yang tepat. ${ }^{59}$

Di sisi lain, bahasa baik lisan maupun tulis dan yang lainnya merupakan alat komunikasi. ${ }^{60}$ Sedangkan komunikasi merupakan penyampaian amanat atau

\footnotetext{
${ }^{58}$ Nuruddin 'Itr, Manhaj fi 'Ulüm al-Hadïth (Beirut: Dar al-Fikr al-Ma'āṣir, 1997), h. 190. h. 29

${ }^{59}$ Abdullah bin Dlaifullah al-Ruhaili, Manhajiyah Fiqh al-Sunnah al-Nabawiyah (t.t.p.: t.p., 2009),

${ }^{60}$ Austria Karl Buhler membedakan fungsi bahasa menjadi tiga: (1) bahasa ekspresif, yaitu bahasa yang terarah pada diri sendiri (si pembicara), (2) bahasa konatif, yakni bahasa yang terarah pada lawan bicara, dan (3) bahasa representasional, yaitu bahasa yang terarah pada kenyataan lainnya (apa saja selain si pembicara dan lawan bicara). Austria Karl Buhler, Theory of Language: The Representational Function of Language (Amsterdam: John Benjamis Publishing Company, 1984).
} 
pesan dari pengirim (penutur) kepada penerima (petutur) melalui saluran berupa sistem tanda. Sebuah komunikasi dapat dikatakan berhasil jika amanat atau pesan yang disampaikan penutur dapat diterima oleh petutur persis sama dengan apa yang ada dalam pikiran penutur. Namun kenyataannya sebuah proses komunikasi selalu dipengaruhi oleh beberapa faktor yang dapat mengurangi kelancaran penyampaian pesan, baik itu berupa suasana hati, konteks, keganjilan alat-alat ucap, keanehan pendengaran, ragam sistem tanda ataupun hal-hal lain yang mempengaruhi kelancaran komunikasi. ${ }^{61}$

Oleh karena itu sebagai langkah yang kedua, pengkaji hadis perlu "melakukan pengkajian tentang otentisitas hadis". Menurut Muhammad al-Ghazali, bahwa keshahihan hadis terletak pada sanad dan matannya. Ada 3 kriteria kesahihan sanad hadis, meliputi: 1) perawi harus ḍābit, 2) perawi harus adil, 3) kriteria perawi ḍābit dan adil harus dimiliki oleh seluruh perawi dalam sanad. Sedangkan untuk kesahihan matan ada 2 kriteria, meliputi: 1) Matan hadis tidak shadh yaitu periwayatan salah seorang rawi atau lebih tidak bertentangan dengan al-Qur'an dan rawi lain yang lebih akurat dan lebih dapat dipercaya. 2) Matan tidak mengandung 'illat qadihah (suatu sebab atau alasan yang mengakibatkan tertolaknya suatu hadis).

Kemudian langkah ketiga, pengkaji hadis perlu "melakukan analisis linguistik struktural dan analisis linguistik pragmatik secara dialektik". Hasil analisis ini untuk membedakan mana teks (naș) yang 'am, mana yang khās, mana yang mutlak, mana yang muqayyad, mana yang muhkam, mana yang mutashābih, mana teks (naș) yang berlaku lokal, temporal, maupun universal, dan seterusnya. Dengan kata lain, di level ini pengkaji berusaha memahami karakteristik nas (teks) hadis dengan pendekatan ilmu bahasa baik struktural maupun prakmatik. Hal ini didasarkan pada kenyataan bahwa secara tekstual hadis merupakan manifestasi dari semua kehidupan Nabi Muhammad saw, tetapi pemahaman terhadap teks tersebut akan selalu berubah sesuai dengan konteks ruang dan waktu manusia. Karenanya hadis selalu membuka diri untuk dianalisis, dipersepsi dan diinterpretasikan (ditafsirkan) dengan berbagai alat, metode dan pendekatan lain untuk mengupas isinya. ${ }^{62}$

${ }^{61}$ Robert Sibarani, Hakikat Bahasa (Bandung: Citra Aditya Bakti, 1992), h. 89.

62Umar Shihab, Editor, Hasan M. Noer, Kontekstualitas al-Qur'an: Kajian Tematik atas Ayat-ayat Hukum dalam al-Qur'an (Jakarta: Penamadani, 2005), h. 4. 
Perbedaan analisis linguistik struktural dengan analisis pragmatik yaitu jika analisis linguistik struktural merupakan pengkajian suatu kalimat atau wacana dengan menjadikan bentuk-bentuk lingual tanpa mempertimbangkan situasi tutur sebagai dasar pengkajian, sehingga penganalisisannya bersifat formal. Maka jika diteruskan dengan menggunakan analisis gramatika secara formal, biasanya penganalisisan secara linguistik struktural itu akan dilanjutkan pada tataran sub klausa, kata, dan morfem. Analisis formal seperti ini tidak akan menangkap maksud penulisan teks, jika memang pendekatan pragmatik untuk melengkapinya tidak digunakan. Sedangkan analisis pragmatik merupakan pengkajian suatu kalimat atau wacana dengan mempertimbangkan situasi tutur yang dapat melahirkan kesimpulan tersirat dalam kalimat atau wacana dari teks yang ada.

Sedangkan peneliti maupun pengkaji hadis umumnya masih terbatas pada analisis struktural yang hanya fokus pada teks yang terpisah dengan konteks. Hal ini akan menghasilkan pemahaman yang formal dan doktrinal. Oleh karena itu analisis linguistik struktural tersebut perlu dilengkapi dengan analisis linguistik pragmatik dalam rangka memahami maksud maupun makna yang tersirat dari teks hadis. Dengan ilmu pragmatik peneliti hadis akan mengkaji situasi tutur yang dapat menimbulkan makna sebenarnya secara langsung. Untuk memahami makna tuturan dari satu ujaran (dalam hal ini teks/ nash), didasarkan pada maksud penutur yang dihubungkan dengan aspek-aspek ilmu bahasa dan aspek-aspek non bahasa. Aspek-aspek ini sangat mempengaruhi makna satuan bahasa, mulai dari kata sampai pada sebuah wacana yang meliputi: 1) diksi, 2) pra-anggapan, 3) tindak ujar, dan 4) implikatur percakapan. Jadi, kajian linguistik pragmatik itu berhubungan langsung dengan tingkah laku pemakai bahasa, yakni antara penutur dan lawan tutur.63

Kedua perangkat analisis bahasa baik struktural maupun pragmatik penting dalam memahami teks hadis karena terkadang suatu bentuk kalimat (sighat) keluar dari makna hakikinya kepada makna majazi. Hal ini bisa diketahui dari konteks yang melingkupinya baik dari konteks kalimat maupun di luar kalimat (سياق الكلام وقر ائن الاحوال).64

${ }^{63} J o h n$ Lyons, Semantics (Cambridge: Cambridge University Press, 1997), h. 114-117.

${ }^{64}$ Ahmad Ba Hamid, Dars al-Balaghah al-'Arabiyyah: al-Madkhal fi 'Ilm al-Balaghah wa 'Ilm alMa'ani (Jakarta: Raja Grafindo Persada, tth.), h. 66, lihat juga Ali Imran, Hermeneutika al-Qur'an Nash Hamid Abu Zayd, dalam Sahiron Syamsuddin, "Kata Pengantar", Hermeneutika al-Qur'an \& Hadis 
Langkah keempat, pengkaji "melakukan verifikasi" terhadap hasil aktifitas intelektual (pemahaman) secara komprehensif, dengan melakukan 4 pengujian $^{65}$ : 1) pengujian dengan al-Qur'an, 2) pengujian dengan membandingkan pada periwayatan hadis yang lain, 3) pengujian dengan fakta sejarah, dan 4) pengujian dengan kebenaran ilmiah. Menurut Yusuf Qardhawi, segala sesuatu yang dinukilkan dari sumber agama (hadis) yang șahịh, maka tidak akan bertentangan dengan apa yang dapat diterima oleh akal secara lurus dan gamblang. ${ }^{66}$ Oleh karena tahap keempat ini adalah tahap implementasi, maka di sini syarih perlu menggunakan pendekatan multidisiplin dan interdisiplin secara dialogis-dialektis. Dalam mengkaji dan memahami hadis, syarih perlu mendialogkan dan mengkorfirmasikan baik dengan ilmu-ilmu keislaman seperti fikih, usūl fiqh, dan lainnya. Juga ilmu-ilmu modern seperti ilmu sosiologi, antropologi, psikologi, ilmu komunikasi, sejarah, dan sebagainya. Hal ini dilakukan secara reflektif untuk mendapatkan meaningfull sense dan implementasi yang tepat.

\section{F. Kesimpulan}

Setiap metode pemahaman hadis tidak ada yang sempurna dan final. Oleh sebab itu, tidaklah tepat jika ada pandangan yang menyatakan bahwa metodenya paling baik dan benar. Sebuah metode terkadang lebih tepat untuk memahami hadis dan konteks tertentu, namun kurang tepat untuk memahami hadis dan konteks yang lain. Jadi, sebuah metode sangat terkait dengan objek (teks/naș) dan konteks. Metode dalam memahami hadis tidak cukup hanya menggunakan pendekatan ilmu hadis dan ilmu keislaman yang lain, namun juga perlu didialogkan dengan ilmu-ilmu modern. Misalnya ilmu-ilmu sosial baik sosiologi, antropologi, psikologi, ilmu sejarah, ilmu bahasa/ linguistik, dan lain sebagainya.

Pemahaman kontekstual terhadap hadis Nabi pada saat sekarang dan di masa yang akan datang adalah suatu keniscayaan. Karena kontekstualisasi terhadap hadis Nabi menjadikan ajaran Islam fleksibel, luwes, dan rasional yang

(Yogyakarta: elSAQ Press, cet. 1, 2010), h. 124-125, lihat juga Prof. Dr. H. Nizar Ali, M.Ag, Memahami Hadis Nabi Metode Dan Pendekannya (Yogyakarta: Idea Press, cet. 2, 2012), h. 117-118.

${ }^{65}$ Keempat tolok muhadditsin dalam kritik matan Hadis penulis kutip dari Muhammad Thahir al-Jawabi, Juhud al-Muhadditsin fi Naqd Matn al Hadits al-Nabawi al-Syarif (t.tp.: Nasyr wa Tauzi' Mu'assasat 'an al-Karim bin Abdillah, t.th.), h. 456.

66 Yusuf Qardhawi, Memahami ..., h. 190. 
sesuai dengan ajaran Islam șāliḥ li kulli zamān wa makān. Namun demikian, kontekstualisasi harus dilakukan secara hati-hati, karena tidak semua hadis bisa dipahami secara kontekstual, misalnya hadis tentang akidah, ibadah, dan hal-hal gaib. Kontekstualiasi harus memperhatikan aspek universal, lokal, dan partikular ataupun situasi dan kondisi tetentu. [

\section{DAFTAR PUSTAKA}

al-Albani, Silsilah Hadis Dla'if dan Maudlu', terj. A.M. Basamalah, Jakarta: Gema Insani Press, 1997.

Ali, Nizar, Memahami Hadis Nabi Metode dan Pendekatannya, Yogyakarta: Idea Press, 2012.

al-Baghdadi, Abu Bakr bin Ali Sabit al-Khatib, Kitāb al-Kifāyah fi 'Ilm al-Riwāyah, Mesir: Matba'ah al-Sa'adah, 1972.

Brown, Daniel W., Menyoal Relevansi Sunnah dalam Islam Modern, terj. Jaziar Radianti \& Entin Sriani, Bandung: Mizan, 2000.

Buhler, Austria Karl, Theory of Language: The Representational Function of Language, Amsterdam: John Benjamis Publishing Company, 1984.

Esposito, John L. (eds.), "Shaykh", The Oxford Encyclopedia of the Modern Islamic World, jilid IV, New York: Oxford University Press, 1995.

al-Ghazāli, Muḥammad, al-Sunnah al-Nabawiyyah bayna Ahl al-Fiqh wa Ahl alHadīth, Kairo: Dār al-Shurūq, 1989.

Studi Kritis atas Hadis Nabi saw antara Pemahaman Tekstual dan Kontekstual, terj. Muhammad al-Baqir, Bandung: Mizan, 1996.

Hamid, Ahmad Ba, Dars al-Balaghah al-'Arabiyyah: al-Madkhal fi 'Ilm al-Balaghah wa 'Ilm al-Ma'ani, Jakarta: Raja Grafindo Persada, t.th.

HAM, Musahadi, Evolusi Konsep Sunnah Implikasinya pada Perkembangan Hukum Islam, Semarang: Aneka Ilmu, 2000.

Harb, Ali, Așilah al-Haqīqah wa Rahanāt al-Fikr: Muqarahāt Naqdiyyah wa Sijaliyyah, terj. Nalar Kritis Islam Kontemporer, Yogyakarta: IRCiSoD, t.th. 
Hidayat, Komaruddin, Memahami Bahasa Agama: Sebuah Kajian Hermeneutik, Jakarta, Paramadina, 1996.

Ismail, Syuhudi, Metodologi Penelitian Hadis Nabi, Jakarta: Bulan Bintang, 1992.

'Itr, Nuruddin, Manhaj fi Ulūm al-Ḥadìth, Beirut: Dār al-Fikr al-Ma’așir, 1997.

al-Jauzi, Abu Farj Abd al-Rahman bin Ali bin, Kitāb al-Mawḍūát, Beirut: Dar alFikr, 1983.

al-Jawabi, Muhammad Thahir, Juhud al-Muhaddithīn fi Naqd Matn al-Hadith alNabawi al-Sharif, Nasyr wa Tauzi' Muassasaat an al-Karim bin Abdullah, 1986.

Kadir, Muslim A., Ilmu Islam Terapan; Menggagas Paradigma Amali dalam Agama Islam, Yogyakarta: Pustaka Pelajar, 2003.

Khaeruman, Badri, Otentisitas Hadis; Studi Kritis Atas Kajian Hadis Kontemporer, Bandung: Rosda Karya, 2004.

al-Khathib, M. 'Ajjaj, Ushul al-Hadits; Pokok-pokok Ilmu Hadits, terj. HM. Qadirun dan Ahmad Musyafiq, Jakarta: Gaya Media Pratama, 1998.

al-Khuli, Muhammad Abd al-Aziz, al-Adab al-Nabawi, Beirut: Dar al-Kutub alIlmiah, 2005.

Lyons, John, Semantics, Cambridge: Cambridge University Press, 1997.

Lubis, Akhyar Yusuf, Postmodernisme Teori dan Metode, Jakarta: RajaGrafindo Persada, 2014.

Filsafat Ilmu Klasik Hingga Kontemporer, Jakarta: RajaGrafindo Persada, 2015.

Mansyur dkk, Metodologi Penelitian Living Qur'an \& Hadis, Yogyakarta: Teras, 2007.

Mukri, Barmawi, Kontekstualitas Hadis Rasulullah: Mengungkap Akar dan Implementasinya, Yogyakarta: Ideal Press, 2005.

Muslim, Imam, al-Jāmi' al-Ṣaḥịh, Surabaya: Salim Nabhan, j. II.

Popper, Karl R, the Open Society and Its Enemies, Princeton: Princeton University Press, 1950. 
Qardhawi, Yusuf, Kaifa Nata'amal ma'a al-Sunnah al-Nabawiyyah, terj. Muhammad al-Baqir, Bandung: Karima, 1993.

- Bagaimana Memahami Hadis Nabi saw. terj. Muhammad al-Baqir, Bandung: Karisma, 1993.

al-Shahwah al-Islämiyyah bayna al-Ikhtiläf al-Mashru' wa al-Tafarruq alMadhmūm, Kairo: Dār al-Shurūq, 2001.

al-Shaikh al-Ghazālī Kamā Araftuhu; Riḥlah Nișf al-Qarn, Kairo: Dār alWafā', 1995.

Qudsy, Saifuddin Zuhri, dkk., Model-model Penelitian Hadis Kontemporer, Yogyakarta: Pustaka Pelajar, 2013.

Rahman, Fazlur, Islamic Methodology in History, Karachi: Central Institute of Islamic Research, 1965.

al-Ruhaili, Abdullah bin Dlaifullah, Manhajizah Fiqh al-Sunnah al-Nabawiyah, t.t.p.: t.p., 2009.

Șalāh al-Din bin Aḥmad al-Aḍabi, Manhaj Naqd al-Matn, Beirut: Dar al-Afaq alJadidah, 1983.

Shihab, Umar, (ed.), Hasan M. Noer, Kontekstualitas al-Qur'an: Kajian Tematik atas Ayat-ayat Hukum dalam al-Qur'an, Jakarta: Penamadani, 2005.

Sibarani, Robert, Hakikat Bahasa, Bandung: Citra Aditya Bakti, 1992.

Suryadi, Metode Kontemporer Pemahaman Hadis Nabi Perspektif Muhammad alGhazali Dan Yusufal-Qardhawi, Yogyakarta: Teras, t.th..

Suryadilaga, M. Fatih, Metodologi Syarah Hadis, Yogyakarta: Suka Press, 2012.

Syamsuddin, Sahiron, ed., Hermeneutika al-Qur'an \& Hadis, Yogyakarta: eLSAQ Press, 2010.

al-Tahḥan, Maḥmūd, Ușūl al-Takhrïj wa-Dirāsat al-Asānid, terj. Ridlwan Nasir, Metode Takhrij dan Penelitian Sanad Hadis, Surabaya: Bina Ilmu, 1995.

'Uwais, Abd al Halim, al-Shaikh Muhammad al-Ghazāli: Marāhil 'Aẓimah fi Hayah Mujāhid 'Ażīm, Kairo: Dār al-Shahwah, 1993. 